\title{
Legal Policy of the Welfare State in the Sphere of Physical Culture and Sports
}

\author{
Soldatov V.Y. \\ Department of theory and history of state and law \\ University of management "TISBI" \\ Kazan, Russia \\ yacovsoldatov@yandex.ru \\ Soldatova A.V. \\ Department of theory and history of state and law \\ University of management "TISBI" \\ Kazan, Russia, \\ soldatovaalena@yandex.ru
}

\author{
Salieva R.N. \\ Department of civil law \\ University of management "TISBI" \\ Kazan, Russia, \\ pandora610@yandex.ru
}

Khairullina A.R.

Department of constitutional and international law University of management "TISBI"

Kazan, Russia

alya_khairullina@mail.ru

\begin{abstract}
The article considers the questions of legal policy in the sphere of physical culture and sport in terms of building the welfare state. Based on the use of General, General scientific and specially scientific methods of conducting scientific activities, research of the concepts of the welfare state, legal policy and sustainable development, as well as the results of scientific research in the sphere of legal regulation of physical culture and sports formulated the conclusion about the necessity of scientific symbiosis of these theories in order to solve the problems in the legal regulation of this sphere, respectively, and in the implementation of human rights in sport and physical education. Justified the proposal on the formation of legal policy in the sphere of physical culture and sports as a management tool positive law, which should contribute to the progressive development of all spheres of society. The foundations of such a policy should be issued in a separate legal act which are of decisive importance for the subsequent legislative acts.
\end{abstract}

Keywords-social state; legal; politics; sports; physical culture; legal regulation; sustainable development.

\section{INTRODUCTION}

The effective legal regulation of social relations in the sphere of physical culture and sports, both professional and Amateur, is the most important conditions for the development and prosperity of any state. The positive dynamics of socioeconomic relations are impossible without corresponding labour (human) capacity, because the health of workers and employees is the key to productivity gains, to ensure full implementation of the working and creative potential. This area of legislative regulation is of particular importance in terms of building the welfare state, a policy which has as the undisputed priority of man, his rights and freedoms as the highest value. Thus, sport and physical culture, in General, constitute one of the activities aimed at improving the physical condition of the person and providing for the development of society not only health and educational impact and political and socio-economic impact. In this regard, particular relevance of the research and development of effective legal policy in the sphere of physical culture and sports.

\section{LITERATURE REVIEW}

The theory of the welfare state (Welfare State, or welfare state) appeared in the political thinking in Germany in the 80ies of the XIX century. The term "social state" for the first time in the world of constitutional practice are enshrined in articles 20 and 28 of the Basic law of Germany of 23 may 1949, Further development of the concept was conducted foreign and domestic researchers. A study of the concept of the welfare state, social human rights in the contemporary legal doctrine is represented by the works Bakulina L. T., Ivanenko A. V., Ivanenko V. S., Miletsky V. P., Postnikov V. G., Shaposhnikov S. P. etc.

The development of the theory of legal policy in the modern Russian legal science at the expense of theoretical, industry-specific empirical research. While scientific work in this field is devoted not only to the definition of the category of legal policy, its specific features, main areas (Zatonsky, V. A., Malko A.V., Matuzov N. And. Nersesyants V. S., Rybakov O. Yu., Tikhonova S. V., K. V. Shundikov etc.), and the new methodological understanding of legal policy, its impact on the methodology of contemporary legal studies (Rybakov O. Yu., Stepanenko R. F.) 
The legal regulation of physical culture and sports, in particular, civil law and General legal analysis of this issue devoted to research'eva S. V., Vaskevich V. P., Medvedev S. A., Ovchinnikova N. A. Chesnokov A. N., Shevchenko O. A., etc.

\section{RESEARCH METHODOLOGY}

Methodological basis of research was made by universal, General scientific and specific scientific methods of conducting research activities. As the main the actual legal methods of cognition used formal legal, comparative legal methods, as well as method of legal modeling.

\section{RESULTS}

The specifics of physical culture and sports associated with the obligatory presence of the needs of society in the appropriate material security of the activity corresponding to the infrastructure. The main elements of such an infrastructure of physical culture and sports include sports halls, stadiums, fitness centers, etc. To address these issues, there have been significant measures of large-scale character, which, to a large extent, contributed to our country in major international sporting events such as world summer Universiade 2013, the Winter Olympic games 2014 and the FIFA confederations Cup 2017, world Cup 2018, world winter Universiade 2019 and several others.

However, developed certain strategic measures for further development of material-technical base of physical culture and sports, which is reflected in the adoption of such legal acts, the Strategy of development of physical culture and sports in the Russian Federation for the period until 2020, the Federal target program "Development of physical culture and sports in the Russian Federation for 2016-2020" and several others.

The adoption of these legal instruments is undoubted evidence of positive trends in the study area. In practice, however, remain unsolved a number of problems in the legal regulation of physical culture and sports, in particular, generated the prevailing view in recent decades the idea of global market regulation of all sectors of the social sphere, including physical culture and sports. It helped to preserve most of social-media structures, previously engaged in organizing and conducting physical and sports activities. This fact gave rise to certain problems in the legal regulation of the status of sports organizations, as well as the exercise of their activities, the basic legal principle according to which the International Charter of physical education and sport declared the promotion of the basic right of every individual to sport and physical education, as well as support the national physical education and sport as an important element of continuous education.

This was followed by a round of outstanding issues with the availability of physical culture and sports, including persons with disabilities. With new urgency, the question arose about the compliance of the state that declared themselves as social, of its obligations to ensure human rights.

Therefore, we believe that the proposed in the scientific literature, interpretation of legal policy as the management of positive law can be fully applicable to the field of physical culture and sports and to have high efficiency.

You must develop a clear, science-based strategies and principles of lawmaking in the sphere of development of physical culture and sports, aimed at a phased, continuous improvement of all elements of the mechanism of legal regulation.

The main directions of legal policy in this area should be formulated in a separate legal act that will be decisive for future legislation. The ideological basis of this instrument should be based on the principles of equality, inviolability and security social human rights.

Due to the fact that the investigated area of public relations has an interdisciplinary nature, the formation of legal policy in the sphere of physical culture and sports as a separate legal act will unify the legal framework to create a unified goal-setting subsequent legislative activity in the regulation of physical culture and sports in various branches of law, which ultimately, will help to fill in existing legislation gaps, to eliminate contradictions and to reform the system of organization and management in the sphere of physical culture and sports.

The main directions of legal policy can be summarized as four: basics of organizational activities on competitions and activities basis of preparation of specialists of high qualification, foundations of information and propaganda support, the basics of management development of physical culture and sports.

\section{DISCUSSION}

The concept of sustainable development, the welfare state, as well as legal policy in the science and practice symbiosis involve interdependence and mutual influence of economic and social sustained development. The use of developed legal policy in the sphere of physical culture and sport can be an effective tool for the management of positive law for its further improvement.

Such a component of the human right to a decent standard of living, as an opportunity to engage in physical culture and sports, as a result of the proposed legal action should become a real, guaranteed by the state.

\section{CONCLUSION}

In the legal regulation of the sphere of physical culture and sports as an important part of the progressive development in all spheres of life of society occurred due to objective changes in the political-legal, socio-economic reality, there are some problems.

In the transition of modern society to the concept of sustainable development, involving the direction of activities of individuals and social institutions for positive change in society, the economy, as before, remains the basis of the implementation of the decisions in the social sphere. However, the observed inverse processes, when the role of social policy in solving problems of economic growth. A good example is the field of physical culture and sports, the level of 
development and availability of which depends the future welfare of the state, including economic.

As the main way of solving in the given sphere of problems is the right, not only in the positivist sense, but in the broad, integrative approach to its interpretation, including natural law. In practice, the fundamental basis, the binder of the positive law in the face of the law and the highest law can be a legal policy based on the principles of the social state of critical, strategic importance to the normative-legal acts.

\section{References}

[1] International Charter of physical education and sport (Adopted in Paris 21.11.1978 at the 20th session of the UNESCO General conference) code of regulations of UNESCO. Moscow: International relations. 1991, pp. 186 - 190.

[2] Of The Russian Federation. Laws. The Constitution of the Russian Federation, adopted by popular vote: Feder. Konst. The law of 12 December 1993 (as amended, amended Laws of the Russian Federation on amendments to the Constitution of the Russian Federation from 30.12.2008 N 6-FKZ, from 30.12.2008 N 7-FCL from 05.02.2014 No. 2-FKZ, from 21.07.2014 No. 11-FCL). RG. 1993.

[3] The decree of the RF Government dated 7 August 2009 \# 1101-R "On approval of Strategy of development of physical culture and sports in the Russian Federation for the period till 2020". URL: http//base. garant.ru.

[4] Resolution of the Government of the Russian Federation from 21.01.2015 No. 30 (ed. by 18.06.2019) "About the Federal target program "Development of physical culture and sports in the Russian Federation for 2016 - 2020". URL: http//base. garant.ru

[5] Bakulina L. T. the welfare state and the principles of liberalism: the problems of correlation. Scientific notes of Kazan state University. Series: Natural Sciences. 2008, vol. 150, 5, pp. 7.

[6] Vaskevich VP Civil-legal regulation of relations in the field of professional sports. Candidate's thesis. Kazan, 2006.

[7] Ovchinnikova N. And. Legal regulation of professional sport in the Russian Federation: General legal analysis. Candidate's thesis. Vladimir. 2008.

[8] Fishermen O. Yu., Tikhonova S. V. Legal policy as the management of positive law: the new version of the theory of legal policy. Lex Russica. 2015, vol. 100, 3. pp. 7-18.

[9] Stepanenko R. F. Theoretical and methodological issues of modern pluralistic consciousness. Herald TISBI. 2017, 1, pp. 222-227.

[10] Lisitsyn-Svetlanov A. G., Mal, ko, A. V., Afanas'ev S. F. The rule of law as a factor of economic development. Herald of the Russian Academy of Sciences. 2018, vol. 88, 2, pp. 119-126.

[11] Malko A. V., Isakov N. V., Mazurenko A. P., Smirnov D. A., Isakov I N. Legal policy as a means to improve lawmaking process. Astra Salvensis. 2018, vol.6, 1, pp. 833-842.

[12] Alexsandr S. Kuznetsov. Russian Professor's meeting. Russian Journal of Physical Education and Sport. 2019, 14(1), pp. 17-22. DOI: 10.14526/2070-4798-2019-14-1-18-24 